Marina V. Jović Djalović*

Univerzitet u Beogradu

Filološki fakultet
УДК

821.521-1 Ђиен Ф.

ДОИ

https://doi.org/10.18485/analiff.2016.28.1.8

\title{
FUĐIVARA ĐIEN I GUKANŠO - POČECI JAPANSKE ISTORIOGRAFIJE
}

\begin{abstract}
Fuđivara Đien (Fujiwara Jien, 1155-1225) je japanski budistički mislilac, pesnik i istoričar.

U radu se daju osnovne karakteristike života i rada Fuđivara Điena u okvirima istorijskih okolnosti kraja perioda Heian i početka perioda Kamakura. Posebna pažnja je posvećena njegovom istorijskom radu Gukanšo i budističkim učenjima koja su neposredno uticala na njegov rad.
\end{abstract}

Ključne reči: Fuđivara Đien, Gukanšo, mappo, kalpe

\section{UVOD}

Još do pojave pisma u svakom narodu su postojala određena istorijska saznanja koja su se pamtila i usmeno prenosila: mitovi, legende, priče i predanja o značajnim događajima, ratovima, vladarima, precima, ritualima, poreklu klanova. Usmena predanja prenosili su pripovedači $(\mathrm{ka}-$ taribe), slobodni ili vezani za klanove. Stari Japanci verovali su u magičnu snagu reči (kotodama), posebno, ako su se imena božanstava (kami) i druga posebna predskazanja izgovarala na pravi način.

Početak istoriografije vezan je u Japanu za pojavu kineskog pisma i kineskih istorijskih tekstova donetih iz Kine i Koreje, koji su služili kao uzor prvim japanskim istorijskim tekstovima. Većina ranih tekstova nestala je u požarima, tako da pre princa Šotokua (Shotoku Taishi) nema sačuvanih istorijskih tekstova. Najstariji postojeći istorijski tekstovi su Kođiki (Kojiki, 712) i Nihon šoki (Nihon shoki, 720), pri

Univerzitet u Beogradu, Filološki fakultet, Studenski trg 3, 11000 Beograd, mvjovic@fil.bg.ac.rs 
čemu je Nihon šoki prvi u nizu od šest zvaničnih istorija poznatih kao rikkokushi. ${ }^{l}$

Kođiki je napisan po nalogu cara Temua (Temmu) (673-688) koji je u težnji da učvrsti vlast carske porodice porodice, naredio 671 godine da se kompilira hronika da bi se ispravile greške i protivurečnosti u poreklu i geneologijama velikih klanova (Minamoto, Soga, Taira,..), kako bi se istaklo božansko poreklo vladajućeg klana. Kođiki i kasnije tekstove Rikkokushi pisali su pojedinci ili grupe dvorana koje je carski dvor imenovao kao zvaničnu komisiju. Ovakav način stvaranja istorijskih tekstova postojao je do kraja 901. kada je zbog slabljenja carske vlasti i nezainteresovanosti vojne vlastele, prekinut rad na zvaničnim istorijama, tako da sedmi deo, Shinkokushi, nije dobio konačan oblik. Time je bio završen period stvaranja državnih istorijskih tekstova, kao hronologije događaja. U daljim periodima istoriografija postaje stvar pojedinaca, menja se karakter teksta, od suvog opisivanja dvorskih i zvaničnih događaja, okreće se, prvo ka savremenim istorijskim temama, ličnostima i događajima, a posle i ka temama toka i razumevanja istorijskih događaja i njihovom tumačenju.

U prvu grupu spadaju istorijske priče (rekishi monogatari) i vojne priče (gunki monogatari) a u drugu grupu radovi koji proučavaju tok događaja i objašnjavaju ga sa stanovišta religioznih doktrina, tada, jedino postoćeg načina mišljenja. Od istorijskih priča treba pomenuti Eiga monogatari, Okagami, Imakagami, i Mizukagami, a od vojnih priča Heike monogatari. Hogen monogatari i Heiđi monogatari.

Druga grupa obuhvata radove koji razmatraju istorijske tokove sa stanovišta doktrina budizma, šintoizma i konfucijanizma među kojima su najznačaj-

1 Rikkokushi obuhvata sledeće tekstove: (1) Nihon Shoki takođe Nihongi- 30 svitaka koji obuhvataju period od mitološkog doba do 697.godine tekst je sastavio O-no Yasumaro 712. a kompletirao Toneri Shinnō 720.godine; (2) Shoku Nihongi takođe Shokki - 40 svitaka koji obuhvataju period 697-791. godine. Tekst su komletirali Fujiwara no Tsugutada i Sugano no Mamichi 797.godine; (3) Nihon Kōki - 40 svitaka koji obuhvataju period 792 -833. Tekst su kompletirali Fujiwara no Fuyutsugu i Fujiwara no Otsugu 840.godine (4) Shoku Nihon Kōki- 20 svitaka koji pokrivaju period 833 -850.godine. Kompletirali su ga Fujiwara no Yoshifusa, Fujiwara no Yoshimi, Tomo no Yoshio, i Haruzumi no Yoshitada in 869.godine. (5) Nihon Montoku Tennō Jitsuroku takođe Montoku jitsuroku - 10 svitaka koji obuhvataju period 850- 858.godine. Kompletirali su ga Fujiwara no Mototsune and Sugawara no Koreyoshi 879.godine. (6) Nihon Sandai Jitsuroku takođe Sandai jitsuroku - 50 svitaka koji pokrivaju period 858 - 887. godine. Kompletirli su ga Fujiwara no Tokihira i Ōkura no Yoshiyuki 901.godine. 
niji: Gukanšo (1220) autor Fuđivara Đien (1155-1225), Đino šotoki (Jinno shotoki 1339) autor Kitabatake Ćikafusa (Kitabatake Chikafusa 1293-1354) i Tokuši joron (Tokushi yoron 1712) autor Arai Hakuseki (Arai Hakuseki 1657-1725).

Imajući u vidu značaj istoriografije za proučavanje civilizacije i kulture, razmatrali smo japansku istoriografiju u srednjevekovnom periodu. U ovom radu razmatraće život i rad prvog japanskog istoričara Fuđivare Điena, osnovne karakteristike njegovog istorijskog rada Gukanšo, a takođe i budistička učenja toga vremena, koja su neposredano uticala na formiranje njegovog istorijskog pogleda. Stavovi Kitabatake Ćikafuse i Arai Hakusekija biće razmatrani u daljim radovima.

\section{FUĐIVARA ĐIEN (1155 - 1225)}

Đien je živeo u vreme značajnih istorijskih promena. Ne ulazeći u prikaz istorijskog toka događaja, naglasićemo samo da je Japan tada iz mirnog i stabilnog života po carskim zakonima u periodu Heian, prešao u nemirni period Kamakura kada je uspostavljen je šogunat (1192) i izvršena promena sistema vlasti. Izvršnu, zakonodavnu i vojnu vlast preuzeo novi vojni stalež - klasa samuraja. Car je ostao u Kjotu, ali je bio lišen ranije vlasti i zadržao je samo cerimonijalne funkcije. Nastao je dugogodišnji period dvovlašća koji je trajao do Meiđi restauracije 1868. godine sa neprekidnom borbom za vlast, posebno intenzivnom u početnom periodu, u kojoj Đien zbog svog aristokratskog porekla nije mogao da ostane po strani.

Đien je rođen 17. maja 1155. godine u Kjotu a umro je 28. oktobra 1225. u 70. godini života u mestu Omi (sada Šiga). Ceo njegov život obeležen je njegovim visokim poreklom. On je bio šesti sin regenta Fuđivara no Tadamićija (Fujiwara no Tadamichi 1097-1164), pripadnika severne grane klana Fuđivara ${ }^{2}$. Tri njegova brata bili su takođe regenti,

2 Porodično ime Fuđivara (Fujiwara) dobio je Nakatomi no Kamatari (Nakatomi no Kamatari) 669. godine kao nagradu od cara Tenđija (Tenji). Kamatarijev sin Fuhito (Fuhito), desni ministar imao je četiri sina i dve kćerke koje je udao za careve Momua (Mommu) i Šomua (Shomu). Četiri Fuhitoova sina koji su takođe zauzimali visoke dužnosti na dvoru, osnovali su četiri osnovne »kuće« odnosno grane klana Fuđivara: Fuđivara no Mućimaro (Fujiwara no Muchimaro) - Nanke - južna grana; Fuđivara no Fusaski (Fujiwara no Fusasaki) - Hokke - severna grana; Fuđivara no Umakai (Fujiwara no Umakai) - Shikike - ceremonijalna grana; Fuđivara no Maro (Fujiwara no Maro) - Kyoke - prestonična grana, što je kasnije postalo osnova za konkurenciju unutar klanova. 
tri sestre bile udate za careve ${ }^{3}$, dok je njega više privlačila verska nego svetovna strana života, tako da se već od detinjstva usmeravao ka verskoj, budistističkoj službi.

Đien je dobio odlično obrazovanje u skladu sa svojim visokim poreklom. Godinu dana posle očeve smrti, 1165. godine, Đien je sa deset godina otišao u Šoren-in (Shoren-in) ${ }^{4}$, gde je tada bilo sedište starešine (zasu) manastira Enrjakuđi (Enryakuji) $)^{5}$ na planini Hiei i centar Tendai budizma. Njegov prvi učitelj bio je princ-monah Kakukai, sedmi sin cara Tobe (1103-1156) koji se odrekao prestola i kasnije (1177) postao glavni strešina manastira Enrjakuđi. Mladi iskušenik zamonašio se sa 13 godina, 1167. godine i uzeo versko ime (homyo) Dokai, koje je posle, oko 1181, promenio u Đien (Đien). Pored toga, kasnije je bio poznat i kao Jošimizu (Yoshimizu) po rezidenciji na Jošimizubo. Posle smrti dvor ga je 1237. god nagradio posthumnim imenom Đićin (Jichin), pod kojim je poznat u kasnijim carskim antologijama.

U manastirskom periodu svog života koji je trajao 31 godinu, Đien je bio potpuno obuzet traženjem prosvetljenja. U njegovoj prvoj biografiji Jichin kasho den zabeležena je težnja za izolacijom od sveta (tonsei) i to da su mu rituali i težnja ka prosvetljenju bili privlačniji od svetovnog života u manastiru (Brown, Ishida 1979: 404-405).

Visoko društveno poreklo garantovalo je brz napredak u hijerarhiji, tako da je već u mladosti Đien dostigao visoke crkvene funkcije. Od 1170. do 1185 . godine bio je na najvišim funkcijama u budističkim hramovima.

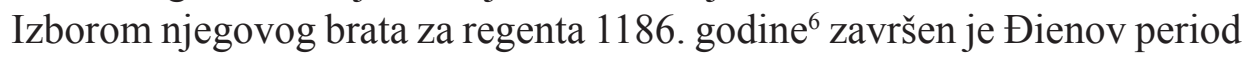
neučestvovanja u politici zemlje.

3 Braća Motofusa (Motofusa) (1144-1230), Motozane (Motozane1148-1166), Kanezane (Kanezane 1149-1207) bili su regenti dok je Kanefusa (Kanefusa 11531217) bio na položaju premijera (dajo daijin). Sestra Seišin (Seishin) bila je supruga cara Sutokua (Sutoku), druga sestra Ikuši (Ikushi) supruga cara Niđoa (Nijo), dok je treća bila udata za cara Konoea (Konoe). (Marra, 1985).

4 Shōren-in - budistički hram u Kjotu, poznat i kao Palata Awata; izgrađen je krajem 13. veka Bio je sedište poglavara sekte Tendai (koji je mogao biti samo pripadnik carske kuće ili drugih najviše rangiranih klanova).

$5 \quad$ Planina Hiei (visine 848,1 m) na severoistoku Kyoto nalazi se na granici prefektura Kjoto i Šiga u Japanu. Hram Enrjakuđi, bio je prvi centar japanske Tendai sekte budizma koji je Saićo (Saicho) utemeljio na Hiei 788 godine

6 Kuđo Kanezane (Kujo Kanezane) bio je regent u periodu 1186 - 1191. kao sessho i 1191 - 1196 kao kampaku 
I pored političke angažovanosti i pomoći bratu, Đien je nastavio da napreduje u crkvenoj hijerarhiji. Uporedo sa ovim položajima, Đien je godinama obavljao i druge brojne funkcije. Bio je dvorski sveštenik cara GoTobe od 1192 do 1196, glavni starešina više manastira i nekoliko drugih hramova, uključujući Šitenođi (Shitennoji), Bjodoin (Byodoin) i naravno, Enrjakuđi na planini Hiei gde je 1192. godine dobio svoj prvi od četiri mandata (Morrell, 1987: 27).

Tokom četvorogodišnjeg mandata glavnog starešine hrama Enrjakuđi, Đien je veliku pažnju posvećivao širenju Tendai budizma: gradio je nove hramove $\mathrm{i}$ učestvovao u organizovanim predavanjima za unapređenje budističkih studija (kangaku ko), čemu je posvećivao posebnu pažnju. Ova predavanja počela su 1195, dok je rasprave napisao kasnije.

Time je Đien nastavio da bude revnosni budista, ali je istovremeno bio preokupiran svim onim što je osiguralavalo prosperitet i moć kuće Kuđo. Politički problemi su ga okupirali isto kao njegovo verovanje u učenje Bude.

Tokom godina uticaj kuće Kuđo se menjao je slabio ili jačao tako da je i Đien odlazio ili se vraćao na položaj glavnog starešine hrama Enrjakuđi na planini Hiei, a time i Tendai sekte. Posle 1195. bio je starešina 1201, 1202. i 1213. godine.

Đien nikad nije mogao u potpunosti da odvoji svoj položaj sina i brata regenta, od svog položaja sveštenika koji je proučavao i praktikovao budizam unutar velike Tendai sekte. Jedno vreme je pokušavao da se izoluje u potpunosti od svetovnih poslova, ali je kasnije bio duboko uvučen u aktuelne političke borbe svog brata, regenta. A kada je uticaj kuće Kuđo počeo da slabi (pogotovo posle smrti Joritomoa) i kada je car Go-Toba insistirao na većoj kontroli carske kuće, Đien je napravio ozbiljan i svestan napor da svoja verska uverenja (i budistička i šintoistička) poveže sa težnjom da promeni sreću kuće Kuđo.

\section{BUDISTIČKA UČENJA}

\section{UČENJE O KRAJU ZAKONA}

Jedno od najznačajnijih učenja u mahajana budizmu je učenje o nestajanju učenja Bude - darme, Zakona, prema kome će, posle odlaska u nirvanu Bude Šakjamunija (Sakyamuni), ljudi postepeno izgubiti njegovo 
učenje, da bi ono kasnije, posle mnogo vekova, ponovo oživelo sa dolaskom Bude Maitreje. Ovo učenje se u potpunosti oslanja na cikličnu promenu u budističkoj kosmologiji vremena, tako da ne predviđa propast sveta već samo privremeni nestanak Budinog učenja.

Učenje o nestajanju Zakona nastalo je u Indiji na podlogama proročanstva o pojavi Dobrog Zakona i njegovom kasnijem pogoršanju i nestajanju, koja su javila veoma rano i dopunjavala se kroz vekove (Lamotte, 1988:192-193). Zajedno sa darmom ovo učenje je preneto je u Kinu u I - II veku, gde je prošireno i, zajedno sa kineskim verzijom budizma, preneto u Japan u VI veku.

Zbog neunificiranosti učenja Mahajane u Indiji, nije postojalo jedinstveno mišljenje o tome koji su svešteni tekstovi najznačajniji za Budino učenje. Zavisno od toga koji tekst i koji metod smatraju najznačajniji za Budino učenje u Kini su stvorene razne škole u kojima su se prevodili, proučavali i dopunjavali Budini tekstovi. Ovo je dovelo do značajnih razlika u pojedinim tekstovima zavisno od toga iz koje škole potiču i da li su indijskog ili kineskog porekla.

U tekstovima vezanim za učenje o nestajanju Zakona, razlikuju se pojedni stavovi, posebno o vremenu nestajanja Zakona. Buda je prorekao nestajanje svog učenja kroz 1000 godina (Bu-ston, 1988; 102), podelivši to vreme na dva perioda po 500 godina koje je obeležio kao period "razvoja" i period "nazadovanja". U Candragarbha-sutra predviđalo se trajanje Zakona 2000 godina, u Munimatalamkara 2500 a u Prajnaparamita-sutra 5000 godina. (Bu-ston, 1988; 103). Slična slika se ponavlja i kod broja i trajanja vremenskih perioda opadanja. Natier prikazuje vreme od 500 do 10000 godina podeljeno na 9 perioda (Nattier 1991: 28-62), Lamote od 500 do 12000 godina podeljeno u 7 perioda (Lamotte, 1988: 192-198), Saićo i Trubnikova od 500 do 1500 godina. Za svaki od ovih perioda daju se odgovarajući prikazi, koje ćemo mi zbog ograničenog prostora izostaviti. Navešćemo samo kratke opise iz teksta Saićoa (Saicho,1994)

U prvih 500 godina posle Budine nirvane sedam mudraca takvih kao Makasjapa podržavaće Istinsku Darmu, garantujući da neće nestati.

Posle 500 godina Istinska Darma će nestati u potponosti.

Posle 600 godina procvetaće nebudistička učenja i doći će mudri pesnik Asavagosa i poniziće ih.

Posle 700 godina doći će veliki filozof Nagarjuna i oboriće sve lažne stavove. 
Posle 800 godina monasi neće želeti da rade već će samo da ispunjavaju svoje želje i biće samo jedan ili dva čoveka koji će postići prosvetljenje.

Posle 900 godina sluge će postati monasi a sluškinje monahinje

Posle 1000 godina oni će postati gnevni kada čuju za budističku praksu očišćenja i neće želeti da je praktikuju

Posle 1100 godina monasi i monahinje će se ženiti i udavati i narušavaće i rugaće se propisima i pravilima.

Posle 1200 godina monasi i monahinje će dobijati decu.

Posle 1300 godina oni će nositi bela odela laika.

Posle 1400 godina četiri grupe učesnika: monasi i manahinje, laici (muškarci i žene)- postaće lovci i prodavaće delove Tri blaga

Posle 1500 godina monasi i monahinje počeće da ubijaju jedan drugog tako da će Zakon nestati.

U "Sutri velike kolekcije" (Chin Ta-chi-ching; Jpn Daijikkyo) vreme posle osme paranirvane Bude Šakjamunija godine 2539. do sadašnjeg vremena podeljeno je u pet perioda od po 500 godina. Ova podela se kasnije javlja kao Teorija pet perioda (Marra, 1988: 26).

Prvi period obuhvata prvih 500 godina od oslobađanja kroz mudrost. U ovom periodu pravi budistički učenici, koji su se saglasili da praktikuju darmu u skladu sa osnovnim idejama, korigovali su karakter, očistili umove, odbacili loše navike i pratili učenje Bude. Oni su takođe meditirali i stekli mudrost. Svi ovi postupci bili su poznati kao oslobađanje kroz mudrost.

Drugi period obuhvata drugih 500 godina i pripada periodu meditacija. U ovom periodu većina pravih učenika vežbala je revnosno, očistila je svoj um i naučili su da razmišljaju u skladu sa učenjem Bude. Oni su, skladu sa sposobnostima i zaslugama, bili u stanju da dostignu više moralne norme.

Treći period obuhvata trećih 500 godina i pripada periodu učenja. U ovom periodu pravi učenici striktno su poštovali skup od dvanaest sutri koje su proučavali i o kojima su diskutovali. Način istinskog prosvetljenja i prirodnog prosvetljenja postaju zanemarivani.

Četvrti period obuhvata četvrtih 500 godina i pripada periodu hramova. U toku ovog perioda većina vernih pristalica potpuno su zanemarili put stvarnog prosvetljenja koristeći prirodno prosvetljenje i praktikovanje bez želje za oslobođenjem. Kroz obuku na ovaj način oni su uživali u nagradama čoveka i bogova nakon smrti. 
Peti period obuhvata petih 500 godina. U ovom periodu učenici su izgubili svoju pravu prirodu, takmičili su se jedan protiv drugog, ispoljavajući mržnju, zavist i nepoverenje, sramoteći jedan drugog. Posebno, oni su se pridržavali svog znanja sutri smatrajući da su u pravu, a osporavali i sramotili jedan drugog da bi se tako domogli slave i bogatstva.

Ovih pet perioda trajali su više od 2500 godina prema budističkom kalendaru. Sav postojeći haos u svetu pripada Poslednjem veku Zakona (Darme), posle koga mnogi naučnici veruju da će nastupiti period povratka Bude Maitreje.

\section{Doba slabljenja Zakona}

Učenje o nestajanju Budinog učenja razmatra ne samo stalno, kontinualno smanjenje njegovog uticaja, u nekom dužem vremenskom razdoblju, već i kvalitativne skokove koji određuju granice između perioda.

U ranom indijskom budizmu vremene slabljenja Zakona deli se na dva perioda: Doba istinskog Zakona i Doba sličnosti Zakona. Natier ukazuje na specifičnuost indijskih spisa vezanih za ovo učenje, da ne sadrže pojam kraja Zakona. Dolaskom budizma u Kinu Učenje o nestajanju Zakona dopunjeno je u VI veku novim periodom - Dobom kraja Zakona. Time je sistem zaokružen i od tada obuvata: (Nattier, 1992: 65-66)

- Doba istinskog Zakona (jap. shobo, ch. chang- fa, skt. saddharma) - period neposedno posle smrti Bude u kome se može dostići prosvetljenje praktikujući učenje Bude;

- Doba sličnosti Zakona (jap. zobo, ch. hsiang-fa, skt. saddaharma - pratimpaka) - period kada se ljudi samo drže slova zakona, ali je suština već zaboravljena; kada je učenje i dalje poznato, ali se ne praktikuje sa onom istrajnošću kao ranije; kada poznavanje učenja postaje formalno, veza sa ljudima slabi i sve je manje ljudi koji mogu da dostignu prosvetljenje.

- Doba kraja Zakona (jap. mappo, ch. mo-fa, skt. saddharma-virapola) - period u kome tradiciona religijska praksa gubi svoju efikasnost i duhovni nivo ljudi pada nedopustivo nisko; kada potpuno nepoznavanje Budinih istina dovodi do opšteg rasula i mrak i neprosvećenost se spušta na svet; kada ljudi više ne mogu da dostignu prosvetljenje kroz Budinu reč, kada društvo postaje raspušteno i kada svet nestaje. 
Trajanje pojedinih perioda razmatra se u više sutri koji navode vremena 500 ili 1000 godina izuzev za Doba kraja Zakona. U tabeli 1 prenete su vrednosti vremena iz rada M. Mare (Marra, 1988: 25)

Tabela 1 Trajanje doba učenja o nestajanju Zakona, prema sutrama

\begin{tabular}{|l|l|l|l|}
\hline \multicolumn{1}{|c|}{ Izvor } & \multicolumn{1}{|c|}{$\begin{array}{c}\text { Doba } \\
\text { Istinskog } \\
\text { Zakona }\end{array}$} & \multicolumn{1}{|c|}{$\begin{array}{c}\text { Doba } \\
\text { Sličnosti } \\
\text { Zakona }\end{array}$} & $\begin{array}{c}\text { Doba } \\
\text { Kraja } \\
\text { Zakona }\end{array}$ \\
\hline Daijosanjusangekyo & 500 & 500 & 10000 \\
\hline Daijikkyo & 500 & 1000 & 10000 \\
\hline Daijikkyo & 1000 & 500 & 10000 \\
\hline Daihikyo & 1000 & 1000 & 10000 \\
\hline
\end{tabular}

\section{Mappo u Japanu}

Učenje o nestajanju Zakona (mappo) preneli su u Japan budistički monasi, ali je ono do sredine perioda Heian bilo u osnovi nepoznato među japanskom aristokratijom. Tek pojačanim uticajem sekta Tendai i Čiste zemlje, oni su u periodu mapo počeli da sagledavaju vreme verske i istorijske krize. Tačan početak Doba kraja Zakona bio je predmet mnogih rasprava u Japanu. U njegovom određivanju figurisale su dve neodređenosti - godina Budinog dostizanja nirvane i trajanje Doba istinskog Zakona i Doba sličnosti Zakona - za koje u sutrama postoji više vrednosti. Kao godine smrti Bude navode 609. i 949. godina pne, dok za trajanje doba 500 i 1000 godina (tabela 1). Kako je do X veka 949. godina pne postala najprihvaćenija za Budinu smrt, a trajanje doba Doba istinskog Zakona i Doba sličnosti Zakona po 1000 godina, za početnu godinu perioda mapoa je određena 1052. godina. (Moerman, 2007: 246). Ukoliko bi se uzelo da Doba istinskog Zakona traje 500 godina, a Doba sličnosti Zakona 1000 godina, za početak perioda mapoa dobila bi se 552. godina, koja nije logična jer se poklapa dolaskom budizma u Japan, posle čega se zemlja uzdiže, što ne odgovara predviđanjima za početak perioda mapoa.

Krajem perioda Heian (794-1185) u Japanu aristokratija je postala svesna nastupanja kraja Zakona. Počele da dominiraju ideje pesimizma što se oslikava u književnosti tog perioda, ali se istovremeno težilo da se umanje posledice kraja Zakona i da se ljudi pripreme da lakše sačekaju neminovnost. Konrad navodi da je u prvoj godini "Kraja Zakona” do tla izg- 
oreo manastir Haseđi (Haseji) u kome su nestali svi sveti prikazi osim malog kipa Bude Amide. Ovo je protumačeno tako da je Amida uvek prisutan i da je spasenje moguće. (Конрад, 1980; 90)

U pripremi za neminovnost, smatralo se da prvo treba sačuvati slovo Zakona za neka dalja pokoljenja. Zato se iskoristio budistički običaj "sahranjivanja sutri”. Sutre su se prepisivale i pojedinačno ili u svežnjevima stavljale u posebne cilindrične kontejnere - stupe, drvene ili metalne, koji su posle smeštani u keramičke posude, koje su zakopavane u plitke jame, sa posebnom spoljnom zaštitom. (Moerman, 2007: 249; 2010: 75)

Pojedinačna spasenja pružala je sekta Čiste Zemlje, vrlo jednostavnim ritualom. Za spasenje i ponovno rođenje u Amidinom raju bilo je potrebno samo ponavljanje reči "Namu Amida Butsu" (Sansom, 1958; 224). Kasnije, u peridu Kamakura, sekta Nićiren (Nichiren) propovedala da je Lotus sutra sredstvo kojim će period kraja Zakona ustupiti mesto novom dobu vere $\mathrm{i}$ da je Nićiren bio bodisatva koji je ponovo rođen da propoveda istinu i čiji je dolazak bio predviđen u dvanaestom i trinaestom poglavlju sutre Lotusovog cveta (Hokke-kyō) (Sansom, 1958; 427).

\section{CIKLIČNA KRETANJA ČETIRI KALPE}

Prema budističkoj kosmologiji vasionu ili kosmos nisu stvorili Bog ili bogovi, već ona postoji oduvek i stalno i nikad neće imati kraj. U vasioni postoji beskonačno mnogo svetova i svi oni egzistiraju paralelno. Ti svetovi nisu statičini već se nalaze u neprekidnom kretanju i u dugim vremenskim periodima prolaze kroz velike cikluse sažimanja i širenja, stvaranja i uništavanja. Trajanje jednog kosmičkog ciklusa sažimanja i širenja određuje veliku kalpu (mahakalpu) koja se deli na četiri obične kalpe, prema vrsti evolucionih promena koji se u njima odvijaju: Samvarta kalpa - kalpa nestajanja; Samvartasthayi kalpa - kalpa nepostojanja; Vivarta kalpa - kalpa stvaranja i Vivartasthayi kalpa - kalpa trajanja. (Sadakata, 102-104) Svaka od ovih kalpi deli se na dvadeset manjih, jednakih, delova, antarakalpi, intermedijalnih kalpi, u kojima prvu polovinu karakteriše porast, a drugu opadanje. Za kalpu Samvartasthayi ova podela samo je formalna, jer se u tom vremenskom periodu ništa ne menja, dok se u ostale tri kalpe u ovim periodima odvijaju unutrašnji ciklusi.

Učenje o velikoj kalpi kao četvorofaznom ciklusu, uključujući i tumačenje procesa četiri kalpe, predstavlja deo budističkog filozofskog nasleđa sakupljenog u enciklopediji Abhidharma kosa, u kojoj je ve- 
liki budistički filozof Vasubandhu (IV vek ne) sistematizovao sve što je budistička filozofska misao sakupila od vremena svog nastajanja.

Obim ovog rada ne dozvoljava detaljnije ulaženje u razmatranje procesa u pojedinim kalpama. Zato će se razmatrati samo osnovne postavke o kalpi nestajanja i kalpi stvaranja koji su od interesa za ovaj rad.

Prikaz učenja o četiri kalpe Vasubandhu započinje sa kalpom nestajanja koja počinje prekidom rađanja i izumiranjem svih živih bića i traje do uništavanja fizičkog sveta vatrom, vodom i vetrom. Kao uzrok pojave ove kalpe navodi se - nestajanje svih rezervi koje su rezultat celokupnih životnih aktivnosti bića. (Васубандху, 37). Posle toga svet se dugo nalazi u stanju praznine, kada je postojala samo akaša ${ }^{7}$. Sledeći ciklus započinje kada se od prikupljene energije celokupne karme svih prethodnih živih bića formira lahor. Pojava prvih vetrića (pragvayu) određuje momenat kraja postojanja starog sveta i početak stvaranje novog sveta. Ovaj momenat određuje početak kalpe stvaranja koja traje do pojave rađanja u sferama pakla. (Vasubandhu (1991): 477; karika 90 c-d).

Za ovaj rad od interesa je kako se Učenje o cikličnim promenama kosmosa povezuje sa darmom, odnosno, u se kom delu ciklusa javlja Buda Šakjamuni. Natier navodi da jedinstvenog stava nema o tome, već stavovi Mahajana i Nikaja (Nikaya) ${ }^{8}$ budizma. (Nattier, 1991: 24-26). Prema Mahajana budizmu, četiri Bude, uključujići i Budu Šakjamunija javljaju se u prvoj antarakalpi kalpe trajanja, dok se peti, Buda Maitreja javlja u maksimumu šeste antarakalpe. Prema Nikaja budizmu, prve četiri Bude javljaju u devetoj antarakalpi, dok se Buda Maitreja javlja u desetoj antarakalpi.

U enciklopediji Abhidharma kosa, karika 94 a-c, navodi se da se Bude javljaju u toku prerioda smanjenja trajanja života ljudi, kada se dužina života smanjila od osamdeset hiljada godina do sto godina. (Vasubandhu, 1991: 481-482; karika 94 a-b)

\section{GUKANŠO}

Gukanšo (Gukansho) je istorijski traktat (shiron) u kome Đien razmatra istorijske događaje i ličnosti i traži istorijsku uzročnost, zakoni-

7 Akaša (आकाश, ākāśa) u indijskim religijama poseban oblik prostora, koji približno odgovara evropskom pojmu etar.

8 Nikaja (Nikaya), opšti naziv za "osamnaest škola" ranog indijskog, sektaškog Budizma, koje su se pojavile pre formiranja Mahajana Budizma 
tosti pojave događaja i sile koje njima upravljaju. Ovo je prvi istoriografski rad u Japanu koji daje celovito učenje o zakonomernostima istorijskog razvoja države na osnovama budističkih teorija.

O autorstvu i vremenu stvaranja Gukanšoa nema direktnih podataka. Tek je 1921. godine Miura Hirojuki (Miura Hiroyuki) dokazao da je Fuđivara Đien autor Gukanšoa, dok su se za vreme objavljivanja japanski naučnici složili da je u pitanju period između 1219. i 1224. godine, sa različitim mišljenjima da li je napisano pre ili posle Đokju nemira 1221. godine. Hembrik smatra da je Đien počeo da piše Gukanšo 1219. godine i da je najveći deo završio do 1220 , dok je određene dopune vršio od 1221. pa do smrti 1225. godine (Hambrick, 1978; 39). Tekst Gukanšoa nije sačuvan u originalu već samo u nekoliko nekompletnih prepisa, koje su japanski naučnici sredili, protumačili i preveli na savremeni japanski jezik i objavili u obliku nekoliko kompilacija tekstova.

Prevoda na evropske jezike ima malo. Za englesku verziju Braun i Išida koristili su kompilirani tekst Marujama Điroa (Jiro Maruyama) iz 1949. godine. U njihovoj interpretaciji, tekst Gukanšoa obuhvata sedam celina: Prva četiri dela vezani su za drevne i srednjovekovne periode i period vojne vlasti, šesti i sedmi daju hronologiju carske porodice od cara Đinmua (Jimmu) do Đuntokua (Juntoku), dok su u petom delu sistematizovani zakljčci i rezimei.

Đien je Gukanšo koncipirao oko tri osnovna stava (Kodansha3, 1986: 65): prvi je poštovanje kontinuiteta carske porodice, drugi su budistička učenja, doktrine i njihova uloga u interpretaciji istorijskih događaja i treći, lična preokupacija Điena - uloga kuće Kuđo u ovim istorijskim promenama, na čemu se u ovom radu nećemo zadržavati.

Gukanšo je napisan katakanom, a ne, kao što je za to vreme bilo uobičajeno, na kineskom. Đien navodi "da bi čitalac mogao da identifikuje i razume Principe i stvarne namere [nevidljivih bića]", ja sam pisao samo o jednosmernom toku istorije, namerno objašnjavajući Principe bez korišćenja nepoznatih reči pokazujući kako su Principi odnosa stvarani u svakom periodu i kako su ovi Principi štitili državu i ljude" (Brown, Ishida, 1979: 202).

\section{PRIKAZ I TOK ISTORIJSKIH DOGAĐAJA}

U prikazu istorijskih događaja, Đien se ne zadovoljava opisom i ocenom događanja, kao u ranijim istorijskim hronikama, već traži zakonitosti 
kojima su oni podređeni. On ih naziva pokretačkim silama istorije (dori) i deli ih nevidljive i vidljive. Skrivene sile su budističko učenje - Zakon i volja bogova (buppo), a vidljive sile su zakon cara, vlasti i ljudi koji su im podređeni $(o b o)$.

Istorijski tok događaja u Gukanšou se prikazuje u tri celine. Prva je hronologija carske porodice, druga je prikaz, komentar i ocena događaja i treća je tumačenje toka u sedam perioda japanske istorije.

Carska hronologija predstavlja geneologiju carske porodice od prvog cara Đinmua (Jimmu) do 86. cara Go-Horikave (Go-Horikawa, 1212-1234). Za svakog vladara Đien navodi njegove lične podatke i godine vladavine, podatke o roditeljima, deci, zatim, imena regenta, glavnih ministra, vođa klanova, a kasnije i verskih poglavara. $U$ vreme vladavine 82. cara Go-Tobe (1180-1239) naveden je Đien na dužnosti prvosveštenika (Brown, Ishida, 1979: 338). Pored toga, kao uvod u hronologiju, daje se kratak pregled kineskih dinastija. Ovaj ogroman materijal Đien je prikupio da bi prikazao kontinuitet carske loze od Boginje Sunca Amaterasu, na čemu je on posebno insistirao, ali i da ukaže da je klan Fuđuvara božanski predodređen da bude najbliži pomoćnik careva. ${ }^{9}$ Ovim Đien, budista po uverenju i obrazovanju, koristi stavove koji su zasnovani na šintoističkim verovanjima.

Japansku istoriju Đien razmatra u širokom opsegu - od najstarijeg doba do njegovog vremena pri čemu je deli na sedam perioda $u$ odgovarajućim periodima učenja o nestajanju Zakona.

Doba Istinskog Zakona

1.Od dolaska na presto 1. cara Đinmua do smrti 13. cara Seimua, 191. godine

9 Varley navodi: "Đien je detaljno opisao kako je Boginja Sunca poslala svog unuka Ninigija sa Ravnine visokog neba sa zadatkom da uspostavi lozu vladara na zemlji. Na osnovu toga imperatorska porodica nalazi se na prestolu Japana od trenutka formiranja zemlje. Kako je svakoj dinastičkoj liniji potrebna je pomoć, posebno kada mladi i nekompetentni vladari treba da stupe na presto, Boginja Sunca je, istovremeno sa Ninigjiem, poslala na zemlju kamija, Ama-no-kojanea, rodonačelnika porodice Fuđivara, da pomogne carskoj kući u neposrednom upravljanju zemljom. Na taj način Amaterasu je proglasila carski klan za centralni, ali je istovremeno razmišljala da će carevima biti potrebna pomoć kvalifikovanh službenih lica, položaj koji je postao posebno značajan za pravilno vođenje poslova tokom srednjih i kasnih (prema određivanju Đien) etapa japanske istorije." (Varley, 20) 
Doba Sličnosti Zakona

2. Od dolaska na presto 14. cara Ćuaia (Chuai) do smrti 30. cara Kimeia (Kimmei), 571. godine

3. Od dolaska na presto 31. cara Bidacua (Bidatsu) do smrti Fuđivara Mićinage (Fujiwara Michinaga) 1027. godine za vreme vladavine 68. cara Go Ićiđoa (Go Ichijo)

Doba Kraja Zakona

4. Od postavljanja Fuđivara Jorimićija (Fujiwara Yorimichi) za regenta do smrti zamonašenog

74. cara Tobe 1156. godine

5. Period vojne uprave, od smrti Minamoto Joritomoa (Minamoto Yoritomo) 1199. godine

6. Početak vladavine 77. cara Go Širakave (Go-Shirakawa) 1155. godine do abdikacije 82. cara Go-Tobe 1198.godine

7. Početak vladavine Go-Tobe kao zamonašenog cara od 1198.godine

Karakteristike pojedinih perioda razni autori objašnjavaju na razne načine. Mi smo konsultovali više radova koji razmatraju problematiku ovih perioda: Braun i Išida (Brown, Ishida 1977), Mara (Marra, 1985), Hambrik (Humbrick 1978), Trubnikova (Трубникова, 2008). U daljem tekstu prvo će biti prikazane osnovne specifičnosti perioda, kompilirane prema stavovima autora koji su po našoj proceni dali najcelovitiju procenu, a zatim principi koji prema Đienu, kontrolišu taj period.

Prvi period (660 god pne - 192 god ne)

Prvi period nastupa odmah posle "ere bogova" i obuhvata vreme vladavine trinaest careva, u periodu japanske istorije poznatom kao Jamato (Yamato): od $1 .{ }^{10}$ cara Đinmua (vladao 660 - 585 god. pne) do 13. cara Seimua (v. 131 - 192 godine ne). U toku ovog perioda skriveni i vidljivi Principi (dori) bili još u harmoniji, careve su nasleđivali sinovi, ali on nije bio obavezan da za naslednika izabere svog najstarijeg sina, već ga je određivao prema sposobnostima. To je bio Doba istinskog Zakona (shobo) kada su, prema Mari (Marra, 1988: 320), skriveni i vidljivi principi (myoken) upućivali na Budistički zakon (buppo) i Imperatorski zakon (oho)

10 Brojevi se navode prema hronologiji datoj u knjizi Brown, Ishida. Sadašnje hronologije ne uračunavaju carice. 
koji su u početku japanske istorije bili identični, stvarajući time srećan karakter drevnih vremena.

Đien pri razmatanju ovog perioda uvodi tri Principa na osnovu kojih analizira vladare. Prvi Princip je vezan za sposobnost (kiryo) nezavisno od pola, za koji navodi da ima najviši prioritet, drugi Princip je da imperatorov sin mora biti odan majci i da joj za života poveri sve prerogative vlasti (Brown, Ishida, 1979: 22). Sledeći Princip je faktor vladavine (sen) po kome je moralno sve što omogućuje vladavinu dobrog vladara. (Brown, Ishida, 1979: 250). Đien to ilustruje događajem iz vremena vladavine cara Đinmua, kada je njegov najmlađi sin, kasnije car Suizei, ubio svog starijeg brata, koji je bio loš i zao čovek. Đien priznaje da je ubistvo naslednika prestola nije dobar korak, ali smatra da bi bilo još veće zlo dozvoliti da zao čovek bude na prestolu kada je raspoloživ drugi, čestitiji pripadnik carske familije. Hembrik u tome vidi dve manifestaciju Principa. Prva je ubisvo lošeg brata, a druga je ubeđivanje dva brata da onaj drugi zauzme presto. (Hambrick p 44).

\section{Drugi period $(192-571)$}

Drugi period obuhvata vladavinu sedamnaest careva u periodu Asuka, od 14. cara Ćuaija (Chuai v. 192 - 200 godine) do smrti 30. cara Kimeija (v. 539 - 571). To je bilo doba Sličnosti Zakona (zobo), kada su vidljivi i skriveni principi počeli da se razdvajaju, ali su ljudi bili još uvek nesposobni da istorijske promene posmatraju kao uticaj rada Principa. U to vreme nasledni prinčevi nisu bili samo sinovi, nego i drugi članovi carske porodice, kao što su unuci i unuke cara. Sposobnost je tada igrala veliku ulogu pri izboru političkih lidera, pri čemu nije pravljena razlika po polovima. (Marra, 1988).

To je bilo vreme dolaska budizma u Japan. Izgubivši neposrednu sposobnost prihvatanja skrivenih osnova u postojećem, realnom svetu, ljudima je bilo potrebno učenje i krajem ovog perioda u Japanu, u vreme vladavine cara Kimeija, počinje da se širi darma i da se uvodi Budistički Zakon.

Već na početku ovog perioda dolazi do nepoštovanja principa nasleđivanja. Kako 13. car Seimu nije imao muško potomstvo, nasledio ga je kao 14. car Ćuai, unuk 12. cara Keikoa, dok je njega nasledila 15. carica Đingu (Jingu), koja je bila njegova žena i regent svom sinu Ođinu (Ojin). Zbog toga Đien primećuje da se u drugom periodu uvodi neka dopuna 
principa nasleđivanja po kome na presto osim sinova mogu doći i žene i rođaci.

Prema Hembriku drugi period se može okarakterisati kao (a) gubitak kontinuiteta nasleđivanja, od oca na sina; (b) pojava žena kao vladara, postepeno smanjivanje moći cara; (c) korišćenje ministara za pomoć carevima; (d) teškoće smeštaja carskih potomaka koji pretenduju na presto (zbog njihove brojnosti); (e) opšte povećanje zla - bezbožnosti kako u vladi tako i među običnim ljudima. (Hambrick, 1978: 45)

\section{Treći period $(572-1036)$}

Treći period traje 464 godine, od vladavine 31. cara Bidacua (Bidatsu v.572-585) do regenta Fuđivara no Mićinage (Fujiwara no Michinaga 966-1027) i 68. cara Go-Ićiđoa ${ }^{11}$ (v. 1016-1036). U tom dugom periodu, koji obuhvata kraj perioda Asuka, ceo period Nara i veći deo perioda Heian, na prestolu je bilo 30 careva i 7 carica. U ovom periodu je klan Fuđivara ojačao i počeo da pruža pomoć carevima, započevši time blisku saradnju sa dvorom.

To je bilo i dalje vreme Sličnosti Zakona (zobo), kada su ljudi želeli da spoje vidljive i skrivene principe u raniju harmoniju, ali to nisu mogli, jer su se odvojili od slova učenja i više nisu mogli da odgovare zahtevima mjošu (myoshu), nevidljivih budističkih i šintoističkih božanstava. To je bila situacija kada su ljudi mislili da je nešto dobro i tako radili, da bi kasnije žalili zbog toga. (Marra, 1985: 321; Brown, Ishida, 1979: 206).

U ovom periodu ubijen je 33. car Sushun, čime je prekršen princip vladavine po kome je car posle krunisanja neprikosnoven, nezavisno od toga koliko je loš, sve dok se dobrovoljno ne izjasni da želi napusti presto i da niko neće biti opravdan ako nagovara cara da se odrekne prestola. Neispunjnje ovog principa smatraće se buntom (Brown, Ishida, 1979: 209). Sushun je drugi ubijeni car. Pre njega nasilno je završio 21. car Anko (453-456).

Početak ovog perioda vezan je za širenje budizma i borbu između klanova Soga, Nakatomi i Mononobe koja je trajala oko 50 godina i završena je pobedom klana Soga, pristalica budizma. Lider klana Soga no Umako bio je ne samo prvi ministar cara Sušina (Sushin) već i njegov rođak, ali se religijski nisu slagali. Car Sušin bio pristalica šintoizma, a

11 Prefiks „Go“ ispred imena japanskog vladara označava drugi, Go-Ichio je Ichio Drugi odnosno, Ichio II. 
Soga no Umako budizma. Kada je car Sušin rešio da udalji Soga no Umakoa iz dvora, on je naredio da ubiju cara (592). Ovo ubistvo imalo je kako politički tako i religijski karakter. Đien opravdava ovo ubistvo principom da budizam brani državu.

Posle smrti cara Sušina, Soga no Umako je na presto, kao 34. cara, postavio svoju nećaku Suiko kao ženu umrlog 26. cara Bidacua. Za njenog regenta postavio je svog drugog nećaka, naslednog princa Šotokua (Shotoku Taishi) koji će kasnije, svojom zakonodavnom aktivnošću, imati odlučujući uticati na formiranje japanske države.

Događaji u trećem periodu nameću nekoliko principa. Primarni je da se posle uvođenja Budističkog Zakona Imperatorski Zakon ne može očuvati bez pomoći Budističkog Zakona (Brown, Ishida, 1979: 25-26). Postavljanjem žene na carski presto, potvrđuje se princip vladara iz prethodnog perioda.

Đien podvlači sledeće elemente kao glavne principe u trećem periodu: samo pripadnici carske porodice (uključujući i malu decu) dolaze na presto; pripadnici porodice Fuđivara služe kao regenti, posebno da bi očuvali presto, a posebno u slučaju kada su nominovani carevi mala deca, slabi ili loši vladari; regenti pomažu da se na presto izaberu najsposobniji kandidati; potreba za regentima javlja se zbog kratke vladavine i/ili brze promene careva; regentura predstavlja mitološku i moralnu obavezu klana Fuđivara. (Hambrick, 1978: 46-47)

Četvrti period $(1017-1156)$

Četvrti period traje 139 godina, od postavljanja Fuđivara Jorimićija za regenta 1017. godine, za vreme vladavine 68. cara Go-Ićiđoa (v.1016-1036), do smrti zamonašenog 74. cara Tobe (1103-156) u poslednjoj četvrtini perioda Heian. (Marra, 1985: 321). Ovaj kratak period ima poseban značaj u Đienovom prikazu istorije, tada počinje slabljenje Imperatorovog Zakona i početak Doba kraja Zakona, mappo, koji se predviđao za 1052. godinu, kada nastaje rasulo i mrak. U ovom periodu još uvek postoje mudri ljudi, ali oni više ne mogu ništa da promene. (Brown, Ishida, 1979: 425)

Četvrti period predstavlja vrhunac vlasti klana Fuđivara i slave njegovih najistaknutijih pripadnika Mićinage i Jorimićija, ali u skladu sa početkom kraja zakona, događaji u njemu nagoveštavaju velike promene. To je u prvom redu opadanje centralne vlasti uvođenjem sistema insei ${ }^{12}$

12 Insei je sistem vladavine zamonašenog impreratora. 
i jačanje vojnog staleža što će dovesti do slabljenja moći cara (dualnost valsti od perioda Kamakura do perioda Meiđi).

Ovi događaji oslabili su principe vladavine uvedene $u$ drugom i trećem periodu - pomoć regenata vladavini careva. Odnosi između nominalnog cara, zamonašenog ali, suštinski, vladajućeg, regenata i vojnika, koji su ranije bili harmonični i obostrani, sada su se pretvarali u otvoreno neslaganje i mržnju. Četvrti period završava se 1156. godine nemirima Hogen kada je neslaganje prešlo u otvoreni rat. (Hambrick, 1978: 48-49)

Peti period (1156-1199)

Peti i šesti period obuhvataju isto vreme, od smrti zamonašenog cara Tobe 1156. do smrti Minamoto Joritomoa 1199.godine, koje u istorijskoj hronologiji, odgovara kraju perioda Heian i početku perioda Kamakura. U budističkoj podeli to je bilo vreme prvih godina Kraja Zakona (mappo).

To je bilo vreme Principa u kome su se ljudi prvo podelili na dva tabora i oštro su se borili između sebe, ali pošto u jednom periodu važi samo jedan Princip, oni koji su pripadali tom Principu pobeđivali su i radili u skladu sa njim. Đien navodi da je nerazumevanje Principa u početku bilo potrebno, da bi se prihvatile vođe, koji su došli u skladu sa Principom, ugledom i vrlinama (itoku) (Brown Ishida, 1979: 207-208). Mara navodi da u ovom periodu mesto mudraca iz četvrtog perioda zauzimaju vođe. (Marra, 1985:322)

Jačanje vojnog staleža u petom periodu vezano je za neprestane međusobne vojne sukobe. To je bilo nemirno vreme, vreme Gempei rata između najvećih vojnih klanova Taira i Minamoto koji je doveo do stvaranja novog centra vlasti, šogunata u Kamakuri, koji je dominirao u Japanu od 1192. do 1333.godine U završnoj bici kod Dan no Ure (1185), udavio se maloletni, četvorogodišnji 81. car Antoku, a sa njim je nestao (potonuo) i carski mač, jedna od regalija japanskog carstva, koji je po predanju Amaterasu - Boginja Sunca, dala prvom japanskom caru. Đien povezuje gubitak carskog mača sa jačanjem vojnog staleža, videvši u tome učešće Boginje Sunca i Velikog bodisatve Haćimana (Hachiman). (Brown Ishida, 1979: 444)

Šesti period (1158-1198)

Šesti period odgovara približno istim godinama kao i peti period, od početka vladavine 77. cara Go-Širakave (1127-1192) kao zamonašenog 
cara, 1158. god, do kraja vladavine 82. cara Go-Tobe (1180-1239), 1198. godine. Međutim, ovo vreme Đien je obeležio kao poseban period, pošto je, usled pogoršanja odnosa između cara i kuće regenta iz kuće Konoe i neprijateljskih odnosa između cara i vojnih vlasti posle smrti Joritomoa, dolazilo da povećanog propadanja zemlje i Đien na to posebno upozorava (Marra, 1985: 322).

To je bio period Principa u kome ljudi nisu mogli da naprave razliku u putu petog perioda, nalazeći se u neprekidnim sukobima jedan sa drugim, puštali su da vreme prolazi bez pronalaženja rešenja. Konačno, kada bi krenuli ka određenom položaju i radili rukovodeći se lošim idejama i osećanjima, pravili bi greške, jer su neput (mudo) razmatrali kao Princip. Ovo je bio princip perioda u kome je postupak (higagoto) bio Princip, ali tada su se pogoršavale sve istorijske promene izvedene postupkom kao Principom, pošto je jedna faza pogoršanja bila praćena onom koja je bila još lošija. (Brown Ishida, 1979: 207-208)

Prema Hembriku u toku petog i šestog perioda zemlja i vlada bili su taoci u borbi polarizovanih strana. Ova polarizacija stvorila je četiri suprostavljene grupacije napetosti: (1) između porodice Taira i regentstva, (2) između porodica Taira i Minamoto, (3) u okviru porodice Minamoto, između Joritomoa, Jošinaka i Jošicunea i (4) borbe na dvoru 1196, između porodica Kuđo i Konoe, grana porodice Fuđivara. Na kraju ovog perioda porodica Minamoto potpuno je uništila porodicu Taira, a porodica Konoe je preuzela mesto regenta. (Hambrick, 1978:49)

\section{Sedmi period (1198-)}

Sedmi period je završni period Đienove hronologije. On počinje vladavinom zamonašenog 82. cara Go-Tobe 1198. godine, na početku perioda Kamakura i početku Doba kraja Zakona (mappo). To je bilo i vreme u kome je živeo i radio Đien. U ovom periodu nije bilo ni mudraca ni vođa i niko se više nije sećao Principa, ni skrivenih ni vidljivih i svet se približavao kraju. (Marra, 1985: 322)

To je bio period Principa po kojima ljudi kada razmišljaju i planiraju nešto, jednostavno ne reaguju na postojeću situaciju, ne razmišljaju o budućnosti, jer je to bilo vreme kad niko nije znao ništa o Principima. To je bio Princip trenutnog vremena (yo) (Brown Ishida, 1979: 208).

Trubnikova navodi (Трубникова 2008: 17) da je Đien u očekivanju opšte propasti video mogućnost suprostavljanja uništavanju i predviđao je 
da će budući vladari Japana umeti da vidljive principe usaglase sa skrivenim. Ovaj Đienov stav bio je u suprotnosti sa učenjem o "kraju Zakona", ali se slagao sa drugim budističkim učenjem - teorijom vremena, koja je izložena u "Enciklopediji Abhidrahme". Ova teorija opisuje promene u celoj vasioni, a ne istoriju stvaranja budističke Darme. U to vreme u Japanu predstave o "kraju Zakona" vezivane sa uništavanjem sveta u celini, ali Đien nije izjednačavao te dve teme. U "Enciklopediji Abhidrahme" svet prolazi četiri velike kalpe, od kojih svaka sadrži dvanaest malih kalpi u kojima takođe postoje periodi rasta i opadanja. Na taj način, ako svet i teži ka nestajanju u toku njegovog opšteg pogoršanja (Samvarta kalpa - kalpa nestajanja) mogući su pojedini periodi relativnog poboljšanja (uzlazni periodi malih kalpi) i u Japanu može da se javi takav period.

Đien navodi da "iako ima pogoršanja postoji takođe i poboljšanja" (Brown Ishida, 1979: 144) i prihvata postojanje Principa koji imaju moć da se suprostave pogoršanju (Brown Ishida, 1979: 209):

1) Princip "rušenja zla i stvaranje dobrog" (metsuzai shozen);

2) Princip "suprostavljanja zlu i podržavanje dobrog” (shaaku jizen);

3) Budističke zapovesti “ Ne radi nikakvo zlo! Radi samo dobro!” (shoaku makusa i shozen bugyo), i

4) Posebni blagoslovi raznih Buda i Bodisatvi (risho hoben).

Đien navodi da se principi ovog perioda razlikuju od principa drugih perioda i da je jedan od novih elemenata bio taj da je za ratnike sada postalo važno da obezbede ulogu u funkcionisanju vlasti. Dokaz da kod vlasti ne postoji razumevanje Principa bila je težnja cara Go-Tobe i njegovih savetnika, da unište vojnu klasu i svu vlast vrate dvoru. Ovo nerazumevanje dovelo je do Đokju nemira 1221. godine i potpunog vojnog poraza dvora. Đien se plašio da će anti-bakufu stavovi cara Go-Tobe dovesti do katastrofalnog kraja plemstva i pokušavao je da spreči takvu mogućnost (Hambrick, 1978: 50).

\section{ZAKLJUČAK}

Đien je bio složena ličnost. Sa jedne strane, bio je budista, po obrazovanju i uverenju koji je u budističkoj hijerarhiji dostigao najviša zvanja i koji je stavove budističke doktrine koristio da objasni tok istorije; sa druge, kao pripadnik ogranka Kuđo klana Fuđivara, koristio svoje vi- 
soke položaje da ojača položaj klana; sa treće, bio je visoki intelektualac kritičkog duha koji je u svom istorijskom delu Gukanšo tražio uzroke i objašnjenje tadašnjeg stanja i puteve prevazilaženja; i sa četvrte, bio je aristokrata, pripadnik tadašnje elite koji je pisao pesme koje su uvrštene u antologiju Šin kokin vakašu (Shin Kokin Wakashu).

Đienov istorijski traktat Gukanšo predstavlja prvi rad u japanskoj istoriografiji koji je nije bio čista hronologija careva i događaja vezanih za vladare. Mada je pisan sa određenim političkim ciljem, da zaustavi dalju konfrontaciju dvora i bakufua, Gukanšo obuhvata svu složenost japanske stvarnosti tog vremena posebno religiozne doktrine budizma, nacionalne stavove šintoizma i moralno-etička učenja konfucijanizma. On prenosi šinto pojam direktnog božanskog porekla cara, konfucijanske pojmove vrlina, reda i harmonije i čitav niz budističkih pojmova kao što su kalpe, tri doba Zakona, principi (dori).

Đien je smatrao da šintoistička i budistička božanstva pokreću tok istorije preko principa koji je prožimaju i određuju pravce njenog kretanja. Prihvatajući cikličnu promenu budističke kosmologije vremena, on je razmatrao cikluse poboljšanja i pogoršanja tražeći načine koji bi omogućili slabljenje procesa pogoršanja. Predlagao je optimističku alternativu u odnosu na tada vladajuću budističku koncepciju slabljenja zakona sa njenim eshatološkim očekivanjima opšteg uništenja i haosa.

\section{Literatura}

Brown D, Ishida I. (1979), The future and the past: a translation and study of the Gukanshô, an interpretative history of Japan written in 1219. Berkeley: Univ. of California Press, Gogle book

Bu-ston, (1988), The History of Buddhism in India and Tibet, Translated from Tibetan by E. Obermiller, Universite Catholique de Louvain, Institute Orientaliste, Louvain la Neuve

Great Collection Sutra, Five period, http://www.phaptangmeditation.org/ D_l-5_2-49_3-49_4-23/, 1.12.2013

Hambrick, C. H. (1978), The Gukanshô: A religious view of Japanese history. Japanese journal of religious studies 5/1, pp 37-58.

Конрад Н.И., (1980), Очерк исйории кульйуры среgневиковой Яйонии, Москва, Искусство 
Lamotte E. (1988), History of Indian Buddhism, from the Origins to the Saka era, Universite Catholique de Louvain, Institute Orientaliste, Louvain -la - Neuve.

Marra M. (1985), The Conquest of Mappo, Jien and Kitabatake Chikafusa, Japanese Journal of Religious Studies Vol. 12, No. 4 (Dec., 1985), pp. 319-341

Marra M. (1988), The Development of Mappo Thought in Japan (I), Japanese Journal of Religious Studies 15/1, pp. 25 - 54

Moerman D.M, (2007), The Archeology of Anxiety, in Heian Japan, Centers and Peripheries, M.Adolphson et all, eds, University of Hawai`s Press, Honolulu.

Moerman D. M, 2010, The Death of the Dharma: Buddhist Sutra Burials in early Medieval Japan in K. Myrvold, ed. The Death of Sacral Texts: Ritual Disposal and Renovationof Texts in World, MPG Group, UK

Morrell R.E. (1987), Early Kamakura Buddhism: A Minority Report, Asian Humanities Press.

Nattier J. (1991) Once upon a future time, Studies in a Buddhist Prophecy of Decline, Nanzan Institute for Religion and Culture, Berkeley, Californoja

Saicho, (1994), The Candle of the Latter Dharma, . BDK English Tripitaka Vol. 107-III. Translated from the Japanese by Robert Rhodes. Numata Center for Buddhist Translation and Research. http://nichirenscoffeehouse.net/books/Candle.html

Sadakata A. (1997), Buddhist Cosmology, Philosophy and Origins, Kosei Publishing, Co, Tokyo.

Sansom G. (1958), A History of Japan to 1334, Stanford University Press, Stanford

Трубникова Н.Н, (2008), Закон іосуgаря и закон буggы, http://trubnikovann.narod.ru/Heian27.htm

Vasubandhu (1991), Abhidharmakosabhasyam, volume II; Translated into French by Louis Poussin, English version by Leo M. Pruden, Berkeley, Calif.: Asian Humanities Press,

Васубандху, (2001) Энщиклойеgия Абхияхармы или Абхияхармакома, разgел ІІІ Лока-Нирgеша, или Учение о Мире, prev. В. И. Рудой, Е. П. Островская, «Ладомир», Москва 2001. 
FUĐIVARA ĐIEN I GUKANŠO - POČECI JAPANSKE ISTORIOGRAFIJE

Marina Jović Đalović

\section{Summary \\ FUJIWARA JIEN AND GUKANSHO BEGININGS JAPANESE HISTORIOGRAPHY}

Fujiwara Jien (1155-1225), a Japanese Buddhist philosopher, poet and historian.

The paper presents the basic characteristics of Fujiwara Jien's life and work in terms of historical circumstances in the late Heian and the early Kamakura period.

Special attention is devoted to his historical work Gukansho and Buddhist teachings.

Key words: Fujiwara Jien, Gukansho, mappo, kalpas 